\title{
Andrea Pfeifer
}

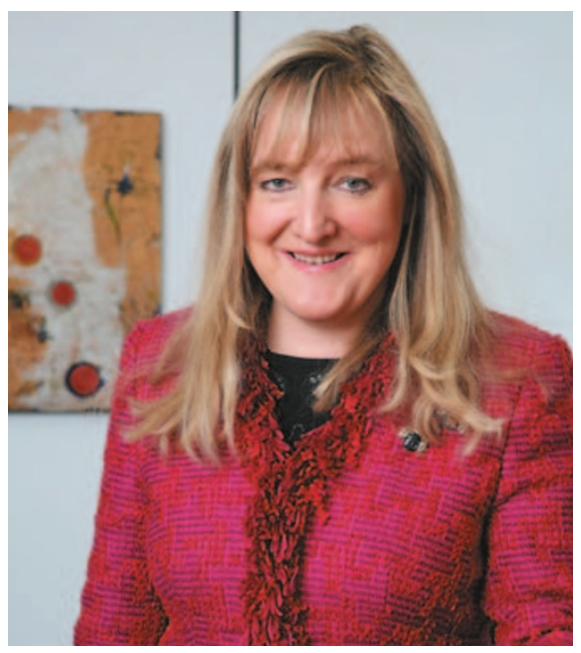

For any scientist, making the leap from research to business can seem a daunting prospect. But lessons can be learned from those who have done it before, like Andrea Pfeifer. Her varied career has seen her move from academic training as a toxicologist to Director of Nestlés Research Centre in Switzerland. There, she was involved in co-founding the company's venture capital arm supporting emerging life science startup companies. She is currently CEO of AC Immune, a biotechnology firm she founded that focuses on CNS diseases and cancer.

Following a degree in Pharmacy and a Ph.D. in Toxicology from the University of Würzburg, Germany, Pfeifer chose the well-trodden path of moving to the US to pursue her research career. "I felt that in medical research, America had the most to offer," she explains. She obtained a National Institutes of Health grant to work in Curt Harris's laboratory of Human Carcinogenesis at the National Cancer Institute. There, she temporarily abandoned her toxicology training in favour of cancer research, focusing on the onco- and tumour suppressor genes — work that ultimately led to a better understanding and therapy of lung cancer.

"It was very rewarding for me to see that these oncogenes I was working on about ten years ago have formed the basis of therapies that were eventually marketed and are actually doing a lot of good," Pfeifer says.

After 5 years, and with some reluctance, Pfeifer returned to Europe to be near to a close relative with cancer, a "very difficult move career-wise". Little did she know that this would mark the beginning of a series of events that would see a fortuitous leap for Pfeifer from scientist to executive.

Thanks to connections of her US supervisor, who was consulting for Nestlé at the time, Pfeifer started working in the genetic toxicology department of the Nestlé Research Centre in Lausanne, Switzerland. She focused on new food safety methods that circumvent animal experimentation. But after only a short time in her role, she took on leading her research group after her supervisor's sudden death from cancer. Now, both personal and professional encounter with cancer illnesses reinforced Pfeifer's determination to work in medical research.

Having proven herself capable of taking on this leadership role, and working her way up through the life-science research department, in 1998, aged 41, she was nominated to become Director of Global Research at Nestlé. She says this surprised her, and some of her colleagues, but she believes her manager appreciated her business sense: "My strength was that I could demonstrate that biological research can actually create fundamentally new products. I think I had the capability of being able to convince management of that," she says. "I was not at all afraid and I really believed in the products I was representing." She adds: "Persistence is something you cannot learn."

Having established herself in this position, Nestlés senior management tried to steer her towards a purely business role. It took some time for Pfeifer to come around to this idea, having spent her entire career in research. But nevertheless she began training for the part. In 1996, she completed an executive business training course at the Institute for Management Development (IMD) in Switzerland, one of Europe's top business schools, and later undertook training in finance at the London Business School.

As soon as she completed her training she was able to gain first-hand business experience taking on the position of science and technology alliance manager at Nestlé. It was here that she learnt the art of deal negotiation and research project valuation. That experience came in handy when she took on an additional responsibility: still working as Head of
Research, she initiated the idea at Nestlé to follow in the steps of big pharma by creating an in-house venture capital fund. Pfeifer was asked to develop and implement the concept in collaboration with a colleague. She was ideally positioned - with the combination of research background and experience of research project valuation - to select and finance promising new start-ups that had potential to bring new products to Nestlés pipeline.

\section{Persistence is something} you cannot learn.

Despite all of these achievements in a corporate environment, medical research remained Pfeifer's main interest. In 2003, she created AC Immune, something she says she couldn't have done without the business experience she gained at Nestlé. "Even after my position as head of research, I don't think I could have succeeded because I was missing that one important part." Her main challenge now is to steer the company to provide a return to investors by following the model of another Swiss company, Actelion, which successfully floated on the Swiss Stock Exchange in 2002.

But a single challenge is not enough for Pfeifer. Today, she is imparting her business knowledge to the next generation of entrepreneurs by teaching regularly at IMD. And after Henri Meier, founder of Swiss venture capital firm HBM, made her an offer she could not refuse, she is now Chair of a Swiss early-stage venture capital fund called Bio Medinvest, dedicated to funding biotech companies in the Alpine rim. It's a role that is useful for when she's wearing her CEO hat: "It is important when you are CEO of a company to have a network. Chairing Bio Medinvest keeps me informed about the biotech world."

Pfeifer believes that scientists interested in business would benefit, as she did, from working in licensing or business development within large pharma or biotech. And as for starting their own company? "If they have an excellent idea, they should partner with somebody they trust and who has proven to be successful in biotech. I would not recommend that anyone without business experience does it alone."

Sabine Louët 